\title{
PERBEDAAN pH SALIVA ANTARA BERKUMUR INFUSED WATER LEMON DAN INFUSED WATER STROBERI PADA PENGHUNI ASRAMA GRIYA BHAKTI HUSADA SEMARANG Sadimin $^{1}$, Irmanita Wiradona ${ }^{2}$
}

\begin{abstract}
ABSTRAK
Derajat keasaman $\mathrm{pH}$ saliva adalah cara untuk mengukur derajat asam atau basa dari cairan saliva. Berkumur merupakan tindakan yang paling sederhana untuk menjaga kebersihan gigi dan mulut. Buah-buahan yang bercita rasa masam dan manis banyak dipilih karena menghasilkan aroma dan rasa yang lebih menyegarkan, seperti lemon dan stroberi yang bisa dipilih untuk membuat infused water. Penelitian ini bertujuan untuk mengetahui perubahan $\mathrm{pH}$ saliva sebelum dan sesudah berkumur infused water lemon dan infused water stroberi.

Metode penelitian ini adalah Quasi Experimental atau Experimental Seтu. Rancangan dalam penelitian ini pretest and posttest with two group design. Pada rancangan ini menggunakan 2 kelompok yang diberi perlakuan yang sama yaitu dengan cara mengukur $p H$ saliva sebelum perlakuan dan sesudah perlakuan. Sampel untuk infused water lemon adalah 40 dan untuk infused water stroberi adalah 40 jadi total keseluruhan sampel ada 80 responden. Analisa data menggunakan distribusi frekuensi dan statistik independen t-test.

Hasil dari penelitian tentang perbedaan $p H$ saliva sebelum dan sesudah berkumur infused water lemon dan infused water stroberi adalah selisih rata-rata $\mathrm{pH}$ saliva sebelum dan sesudah berkumur infused water lemon adalah 0,3. Sedangkan untuk selisih rata-rata sebelum dan sesudah berkumur infused water stroberi adalah 0,4. Keduanya sama-sama bisa menurunkan $\mathrm{pH}$ saliva, akan tetapi yang lebih banyak menurunkan $\mathrm{pH}$ saliva adalah sesudah berkumur infused water stroberi. Saran perlu dilakukan penelitian lebih lanjut dengan buah yang berbeda seperti anggur, kiwi, belimbing.
\end{abstract}

Kata Kunci : Derajat Keasaman pH Saliva, Infused Water Lemon dan Stroberi

\begin{abstract}
The degree of acidity of $\mathrm{pH}$ saliva is a way to measure the degree of acid or alkaline of the saliva liquid. Gargling is the simple way to maintain the cleanliness of the teeth and the mouth.the fruits which contain of sour taste are chosen, strawberry and lemon fruits are chosen than any other fruits because they contain sour taste and produce fresh taste. They can use to make infused water. The objectives of this research are to determine the alteration of $\mathrm{pH}$ saliva before and after given treatment or gargling using strawberry and lemon infused water.
\end{abstract}

The researcher used Quasi Experimental or Experimental Pseudo Method. The researcher used pretest and posttest in the research design. The researcher divided two group designs. Both of them were given the same treatment by measuring the $\mathrm{pH}$ saliva before and after giving treatment. The sample of lemon infused water are 40 and the strawberry are also 40 , so the total of the sample are 80 responden. Data analysis uses independent frequency and statistical distribusi of t-test.

The result of the research are about the difference of $\mathrm{pH}$ saliva before and after given the treatment using lemon and strawberry infused water. The difference of average of $\mathrm{pH}$ saliva before anf after given the treatment using lemon infused water is 0,3 . Then, the difference of average of $\mathrm{pH}$ saliva before and after given the treatment using strawberry infused water is 0,4 . In conclusion, both of them are equally can recude $\mathrm{pH}$ saliva, but using strawberry infused water work much better than lemon. The need to do more of this research is using different fruit, such as grape, kiwi, and star fruit.

Keywords : The degree of acidity of PH saliva, Lemon and Strawberry infused water

1,2 Dosen Jurusan Keperawatan Gigi Poltekkes Kemenkes Semarang

\section{PENDAHULUAN}

Kesehatan gigi dan mulut merupakan salah satu bagian dari bidang hukum kesehatan, hal tersebut berdasarkan pasal 93-94 Undang-Undang Nomer 36 Tahun 2009 tentang Kesehatan. 
Pemerintah telah menjamin masyarakat dalam pelayanan kesehatan gigi dan mulut dengan menyediakan tenaga kesehatan yang profesional dalam bidang kesehatan gigi dan mulut. (Hendrik, 2012)

Pembangunan di bidang kesehatan gigi merupakan bagian integral dari pembangunan kesehatan secara umum. Penyakit gigi dan mulut merupakan penyakit yang tersebar luas di masyarakat Indonesia. Faktor penyebab dari penyakit gigi dan mulut dipengaruhi oleh faktor lingkungan, perilaku dan pelayanan kesehatan gigi dan mulut (Alhamda, 2011). Prevalensi nasional masalah gigi dan mulut adalah $25,9 \%$ mempunyai masalah gigi dan mulut diatas angka nasional, prevalensi penduduk dengan masalah gigi dan mulut menurut kelompok umur 15-24 tahun adalah 24,3\% (Riskesdas, 2013).

Mulut merupakan tempat masuk beraneka ragam makanan dan minuman masuk kedalam tubuh melalui mulut. Dan di dalam rongga mulut terdapat air liur merupakan campuran dari berbagai cairan. Saliva berfungsi sebagai cairan pembersih dalam mulut, sehingga diperlukan dalam jumlah yang cukup. Tingkat keasaman saliva juga berpengaruh terhadap timbulnya lubang gigi atau karies. Semakin asam, semakin mudah terjadinya karies (Pratiwi, 2007).

Saliva adalah cairan eksoktrin yang terdiri dari 99\% air, berbagai elektrolit yaitu sodium, potassium, kalsium, kloride, magnesium, bikarbonat, fosfat, dan terdiri dari protein yang berperan sebagai enzim, immunoglobin, antimikroba, glikoprotein mukosa, albumin, polipeptida, dan polipeptida yang berperan dalam menjaga kesehatan rongga mulut (Pratiwi, dkk, 2014).

Potensial of hydrogen $(\mathrm{pH})$ adalah suatu cara untuk mengukur derajat asam atau basa dari cairan tubuh. Skala pH berkisar dari 0-14, dengan perbandingan terbalik, semakin rendah pH saliva, maka akan semakin banyak asam dalam larutan. Semakin meningkatnya $\mathrm{pH}$, maka akan semakin banyak basa dalam larutan. Saliva dikatakan netral apabila $\mathrm{pH}=7$ yang berarti bahwa saliva tersebut tidak pada suasana asam ataupun basa. Air ludah secara normal sedikit mengandung $\mathrm{pH}$ asam, yaitu 6,5 dan dapat berubah sedikit dengan perubahan kecepatan aliran dan perbedaan waktu dalam sehari. Makin rendah $p H$ saliva maka karies lebih cenderung semakin tinggi. Beberapa faktor yang menyebabkan terjadinya perubahan pada $\mathrm{pH}$ saliva antara lain rata-rata kecepatan aliran saliva, pola makan, mikroorganisme rongga mulut, dan kapasitas buffer saliva (Besford, 1996)

Dari berbagai macam buah-buahan yang paling sering kita jumpai salah satunya adalah buah jeruk. Dari berbagai macam jenis buah jeruk, salah satunya yaitu jeruk lemon. Jeruk Lemon (Citrus Limon(L.) Burm.f) merupakan tumbuhan berbunga anggota marga citrus dari suku Rutaceae (jeruk-jerukan). Buah Lemon (Citrus Limon(L.) Burm.f) memiliki ukuran 
sekitar 7-12 cm dan memiliki bentuk bulat telur dengan ujung yang runcing pada salah satu ujungnya. Buah lemon yang baik berwarna kuning tua, padat, dan berdaging tebal dengan permukaan kulit mengkilap dan rata (Morton, 1987 dalam Kristanto, 2013). Di dalam buah jeruk lemon terdapat banyak sekali khasiat yang bermanfaat untuk kehidupan manusia. Khasiat yang terdapat pada jeruk lemon itu antara lain sebagai anti hipertensi, tonik, anti bakteri, anti inflamasi, diuretik, dan lebih aromatik. Sebab ternyata kandungan dalam kulit jeruk juga sangat komplek dan menjadikannya komponen yang juga bisa dimanfaatkan dalam kehidupan manusia, seperti zat pektin, minyak atsiri atau minyak etiris, dan senyawa limonen. Kandungan dalam kulit jeruk yang satu ini banyak berguna untuk manusia (Felix, 2011).

Stroberi pertama kali ditemukan di Perancis sekitar tahun 1750. Menurut Hartanti (2013) Buah stroberi sendiri berasal dari bunganya yang berwarna putih, buahnya ada yang berwarna merah cerah, dan juga yang merah pekat. Rasanya asam - manis, dan segar karena berair. Stroberi memiliki keunikan karena biji-bijinya terdapat di seluruh permukaan lapisan kulit dan dagingnya. Umumnya, stroberi hanya tumbuh di daerah dataran tinggi dengan iklim yang sejuk. Karenanya, di Indonesia kebun stroberi banyak ditemukan di daerah pegunungan di Jawa Barat.

Keunggulan atau keistimewaan infused water dibandingkan jus adalah tidak mengandung bahan tambahan seperti gula sedangkan untuk jus bisa mengandung bahan tambahan gula, madu, dan susu, untuk infused water rasanya lebih segar, khas air putih tetapi memiliki aroma buah, praktik dalam pembuatan dan penyajiannya serta memberikan nutrisi segar bagi tubuh sesuai dengan buah dan herba yang dimasukkan ke dalamnya (Murtie \& Yahya, 2014). Hanya saja buah-buahan yang bercita rasa masam dan manis banyak dipilih karena menghasilkan aroma dan rasa yang lebih menyegarkan. Buah-buahan ini seperti lemon, jeruk, mentimun, anggur, belimbing, dan stroberi yang bisa dipilih untuk membuat infused water. Sebaliknya buah-buahan berdaging lunak seperti pepaya, pisang, dan semangka tidak dianjurkan untuk digunakan. Bukan karena kandungan gizinya namun tekstur buah-buahan tersebut mudah hancur jika direndam dalam air dalam waktu yang lama (Wardhana, 2014)

Dalam penelitian ini peneliti menggunakan buah jeruk lemon dan buah stroberi yang akan dibuat atau disajikan seperti infused water untuk bahan penelitian tetapi hanya untuk berkumur saja, Karena pada buah lemon dan stroberi ini banyak mengandung air dan serat dimana kandungan air dalam jeruk lemon dan stroberi ini mengandung asam dimana rangsangan asam sangat mempengaruhi perubahan $p H$ Saliva. 
Tujuan penelitian ini adalah ingin mengetahui perubahan $\mathrm{pH}$ saliva sebelum dan sesudah berkumur infused water lemon dan sebelum dan sesudah berkumur infused water stroberi.

\section{METODE PENELITIAN}

Penelitian ini adalah Quasi Experimen atau Experimen Semu, yaitu suatu penelitian dengan adanya suatu perlakuan terhadap kelompok sampel tetapi tidak ada kelompok kontrol (semua kelompok sampel mendapatkan perlakuan) (Notoatmodjo, 2010). Semua sampel diberi perlakuan yang sama dengan cara mengukur $p H$ saliva sebelum dan sesudah berkumur infused water lemon dan infused water stroberi. Jenis penelitian ini menggunakan deskriptif kuantitatif.

Rancangan dalam penelitian ini adalah pretest and posttest with two group design, gambaran rancangan penelitian sebelum dan sesudah penelitian.

Rancangan penelitian ini dapat digambarkan sebagai berikut :

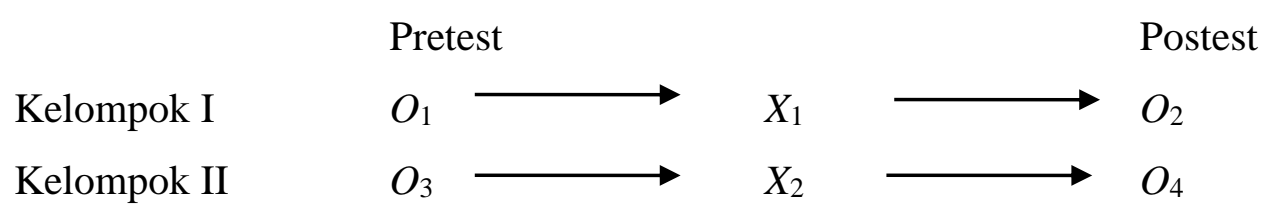

Keterangan :

$O_{1}$ : Pengambilan pengukuran $p H$ saliva sebelum berkumur infused water lemon

$X_{1}$ : Perlakuan kelompok 1 yaitu berkumur infused water lemon

$\mathrm{O}_{2}$ : Pengambilan pengukuran $\mathrm{pH}$ saliva sesudah berkumur infused water lemon

$\mathrm{O}_{3}$ : Pengambilan pengukuran $\mathrm{pH}$ saliva sebelum berkumur infused water stroberi

$X_{2}$ : Perlakuan kelompok 2 yaitu berkumur infused water stroberi

$\mathrm{O}_{4}$ : Pengambilan pengukuran $\mathrm{pH}$ saliva sesudah berkumur infused water stroberi

Populasi dalam penelitian ini adalah penghuni Asrama Griya Bhakti Husada di Semarang dengan jumlah 321 orang. Dalam penelitian ini sampel yang diambil yaitu 25\%. Cara pengambilan sampel ini menggunakan teknik random sampling yaitu dari 321 x 25\%=80,25 dan dibulatkan menjadi 80 dibagi menjadi 2 responden, sehingga untuk sampel yang digunakan sebanyak 40 responden untuk infused water lemon dan infused water stroberi 40 responden juga.

Data hasil penelitian disajikan dalam bentuk tabel distribusi frekuensi. Perbedaan $p H$ saliva sebelum dan sesudah berkumur infused water lemon dan sebelum dan sesudah berkumur infused water stroberi menggunakan uji statistik pait t-test. Untuk mengetahui 
selisih perbedaan $p H$ saliva antara berkumur infused water lemon dan infused water stroberi menggunakan uji independen t-test.

\section{HASIL DAN PEMBAHASAN}

Penelitian dengan judul "Perbedaan pH Saliva Antara Berkumur Infused Water Lemon Dan Infused Water Stroberi” pada penghuni Asrama Griya Bhakti Husada Semarang yang berjumlah 80 responden, 40 responden mendapat perlakuan berkumur infused water lemon dan 40 responden mendapat perlakuan infused water stroberi. Hasil pemeriksaan dan penelitian didapatkan hasil sebagai berikut :

Tabel 1 Distribusi frekuensi nilai pH saliva sebelum dan sesudah berkumur infused water lemon

\begin{tabular}{ccccc}
\hline pH saliva & \multicolumn{2}{c}{ Sebelum } & \multicolumn{2}{c}{ Sesudah } \\
\cline { 2 - 5 } & $\mathrm{N}$ & $\%$ & $\mathrm{n}$ & $\%$ \\
\hline Asam & 18 & 45 & 20 & 50 \\
Netral & 10 & 25 & 4 & 10 \\
Basa & 12 & 30 & 16 & 40 \\
\hline Jumlah & 40 & 100 & 40 & 100
\end{tabular}

Berdasarkan Tabel 1 dapat dilihat frekuensi $p H$ saliva terbesar sebelum perlakuan dengan kategori asam sebanyak 18 responden (45\%) sedangkan setelah perlakuan mengalami kenaikan frekuensi $p H$ saliva dengan kategori asam sebanyak 20 responden (50\%).

Tabel 2 Distribusi frekuensi pH saliva sebelum dan sesudah berkumur infused water stroberi

\begin{tabular}{ccccc}
\hline pH saliva & \multicolumn{2}{c}{ Sebelum } & \multicolumn{2}{c}{ Sesudah } \\
\cline { 2 - 5 } & $\mathrm{N}$ & $\%$ & $\mathrm{n}$ & $\%$ \\
\hline Asam & 23 & 57,5 & 33 & 82,5 \\
Netral & 8 & 20 & 6 & 15 \\
Basa & 9 & 22,5 & 1 & 2,5 \\
\hline Jumlah & 40 & 100 & 40 & 100 \\
\hline
\end{tabular}

Berdasarkan Tabel 2 dapat dilihat frekuensi $p H$ saliva terbesar sebelum perlakuan dengan kategori asam sebanyak 23 responden (57,5\%) sedangkan setelah perlakuan mengalami kenaikan frekuensi $p H$ saliva sebanyak 33 responden $(82,5 \%)$. 
Tabel 3 Distribusi Rata-rata Selisih pH Saliva Sebelum Dan Sesudah Berkumur Infused Water Lemon Dan Infused Water Stroberi

\begin{tabular}{cccc}
\hline \multirow{2}{*}{ Kelompok } & \multicolumn{3}{c}{ Hasil Penelitian } \\
\cline { 2 - 4 } & Sebelum & Sesudah & Selisih \\
\hline Infused water lemon & 6,9 & 6,6 & 0,3 \\
Infused water stroberi & 6,8 & 6,4 & 0,4 \\
\hline
\end{tabular}

Berdasarkan Tabel 3 dapat dilihat rata-rata $p H$ saliva sebelum berkumur infused water lemon yaitu 6,9 dan setelah berkumur infused water stroberi $p H$ saliva mengalami penurunan dengan rata-rata menjadi 6,6 yaitu dengan selisih 0,3 . Sedangkan rata-rata $p H$ saliva sebelum berkumur infused water stroberi yaitu 6,8 dan setelah berkumur infused water stroberi mengalami penurunan rata-rata menjadi 6,4 yaitu dengan selisih 0,4 .

Tabel 4 Hasil uji pair t-test antara kelompok berkumur infused water lemon dan infused water stroberi

\begin{tabular}{lccc}
\hline \multicolumn{1}{c}{ Kelompok } & $\begin{array}{c}\text { Nilai Mean } \\
\text { Sebelum } \\
\text { Berkumur }\end{array}$ & $\begin{array}{c}\text { Nilai Mean } \\
\text { Sesudah } \\
\text { Berkumur }\end{array}$ & $\begin{array}{c}\text { Signifikansi } \\
(p \text { value })\end{array}$ \\
\hline Infused Water Lemon & 6,9 & 6,6 & 0,450 \\
\hline Infused Water Stroberi & 6,8 & 6,4 & 0,022 \\
\hline
\end{tabular}

Hasil uji independent $t$-test menunjukkan bahwa $\mathrm{p}<0,05$ yaitu 0,001 yang berarti bahwa ada perbedaan $p H$ saliva antara berkumur infused water lemon dan infused water stroberi.

Berdasarkan hasil frekuensi perubahan $p H$ saliva sesudah berkumur infused water lemon yang paling banyak yaitu 50\% dengan kriteria asam. Menurut Felix (2011) infused water lemon mempunyai rasa agak pahit dan asam dikarenakan kandungan dalam kulit buah lemon mengandung tanin yang berfungsi sebagai anti bakteri dan anti oksidan serta pada buah lemon juga mengandung asam folat dan karbohidrat yang cukup tinggi sehingga setelah berkumur infused water lemon kebanyakan $\mathrm{pH}$ di bawah 7 dan itu menyebabkan keasaman dalam rongga mulut. Menurut Prasetyo (2005) Makanan dan minuman yang bersifat asam ternyata memiliki kandungan asam folat. 
Hasil frekuensi sesudah berkumur infused water stroberi yang paling banyak yaitu 82,5\% dengan kriteria asam. Menurut Rukmana (1999) pada buah stroberi juga mengandung karbohidrat yang cukup tinggi sehingga setelah berkumur infused water stroberi menyebabkan keasaman dalam rongga mulut. Menurut Amerongen (1991) derajat asam dipengaruhi oleh diet kaya karbohidrat, dengan diet karbohidrat dapat menurunkan kapasitas buffer dan menaikan metabolisme produksi asam pada rongga mulut. Hasil penelitian dan hasil uji independen t-test menunjukkan infused water stroberi lebih berpengaruh ke arah asam dibandingkan pada infused water lemon.

Beberapa hasil penelitian tentang infused water buah dan sayur juga dapat mempengaruhi perubahan $p H$ saliva. Diantaranya penelitian Suhartatik dkk (2013) tentang menguji infused water dengan beberapa buah ternyata buah jeruk nipis dan stroberi memiliki pH paling asam yaitu $(3,85)$. Menurut Subekti dkk (2014) tentang penelitian berkumur dengan daun herbal dibandingkan dengan aquades tidak menunjukkan perubahan pada $\mathrm{pH}$ saliva.

Selisih rata-rata $p H$ saliva sebelum dan sesudah berkumur infused water lemon adalah 0,3 sedangkan selisih rata-rata $p H$ saliva sebelum dan sesudah berkumur infused water stroberi adalah 0,4 . Selisih perubahan rata-rata $p H$ saliva infused water stroberi lebih tinggi dibandingkan dengan selisih perubahan infused water lemon. Dan perbedaan rata-rata selisih perubahan $p H$ saliva diantara infused water tersebut yaitu $(0,1)$. Dari hasil pembahasan diatas, dapat diketahui bahwa kandungan senyawa yang sama terkandung dalam lemon dan stroberi adalah karbohidrat, sehingga pada kandungan tersebut mempunyai efek dapat menurunkan pH saliva. Hal ini merupakan kelemahan dari peneliti, karena peneliti hanya meneliti perbedaannya saja, tidak sampai mengetahui perbandingan kandungan karbohidrat dari kedua kelompok yang dapat mempengaruhi perubahan $p H$ saliva, tetapi pada perubahan pH saliva untuk berkumur infused water lemon dan infused water stroberi kurang baik karena cenderung menurunkan $\mathrm{pH}$ saliva menjadi asam. Penelitian ini responden dikendalikan sesaat dengan cara sebelum berkumur infused water sampel di intruksikan untuk berkumur air putih terlebih dahulu tujuannya untuk membuat homogen di dalam rongga mulut sehingga sebelum perlakuan $p H$ saliva responden dalam keadaan yang hampir sama. Menurut Ganong (1999) kemungkinan faktor lain yang mempengaruhi perbedaan $p H$ saliva yaitu status psikologi dan perubahan hormonal, faktor lainnya yaitu kebiasaan dan keadaan mulut responden di antaranya apakah ada karies dan karang gigi yang dapat berpengaruh. 


\section{KESIMPULAN}

Berdasarkan hasil penelitian Perbedaan $\mathrm{pH}$ saliva antara berkumur Infused Water Lemon dan Infused Water Stroberi pada penghuni Asrama Griya Bhakti Husada maka dapat diambil kesimpulan sebagai berikut :

1. Nilai $p H$ saliva sebelum berkumur infused water lemon sebagian besar dalam kategori $\mathrm{pH}$ asam sebesar 18 responden (45\%)

2. Nilai $p H$ saliva sesudah berkumur infused water lemon sebagian besar dalam kategori $\mathrm{pH}$ asam sebesar 20 responden $(50 \%)$

3. Nilai $p H$ saliva sebelum berkumur infused water stroberi sebagian besar dalam kategori $\mathrm{pH}$ asam sebesar 23 responden $(57,5 \%)$

4. Nilai $p H$ saliva sesudah berkumur infused water stroberi sebagian besar dalam kategori $\mathrm{pH}$ asam sebesar 33 responden $(82,5 \%)$

5. Selisih nilai rata-rata $p H$ saliva sebelum dan sesudah berkumur infused water lemon adalah 0,3 dan selisih nilai rata-rata $p H$ saliva sebelum dan sesudah berkumur infused water stroberi adalah 0,4 .

6. Ada perbedaan perubahan $\mathrm{pH}$ saliva sebelum dan sesudah berkumur infused water lemon dan sebelum dan sesudah berkumur infused water stroberi.

\section{DAFTAR PUSTAKA}

Alhamda, S, 2011, Status Kebersihan Gigi dan Mulut dengan Status Karies Gigi (Kajian pada Murid Kelompok Umur 12 Tahun di Sekolah Dasar Negeri Kota Bukit tinggi) :Jurnal Berita Kedokteran Masyarakat, Vol.27 , No.2, h.108.

Amerongen, A, 1991, Ludah Dan Kelenjar Ludah Arti Bagi Kesehatan Gigi Gajah Mada University Press, Yogyakarta.

Besford, J, 1996, Mengenal Gigi Anda Petunjuk Bagi Orangtua : Arcan, Jakarta.

Dalimartha, S, Felix, A, 2011, Khasiat Buah dan Sayur, Penebar Swadaya : Jakarta.

Ganong, W.F, 1999, Gambaran Konsumsi Yoghurt Terhadap Waktu Peningkatan Ph Saliva : Jurnal Ilmiah Farmasi, Vol.4, No.1, Tahun 2015, h.49.

Hendrik, 2012, Etika dan Hukum Kesehatan, Buku Kedokteran : Jakarta

Kristanto, F, 2013, Kekerasan Permukaan Enamel Gigi Manusia Setelah Kontak Dengan Air Perasan Citrus Limon, Skripsi, Fakultas Kedokteran Gigi, Universitas Airlangga, Surabaya.

Murtie, A, Yahya, M, 2014, Infused Water : PT Buana Ilmu Populer, Jakarta.

Notoatmodjo, S , 2010, Metodologi Penelitian Kesehatan :Rineka Cipta, Jakarta. 
Prasetyo, E.A, 2005, Kelarutan Fosfat Email Pada Perendaman Gigi Dalam Minuman Isotonik Dan Asam Folat, Skripsi, Universitas Hasanudin Makasar.

Pratiwi, 2014, Efektivitas Penggunaan Infusum Daun Sirih (Piper betle Linn)50\% dan 100\% Sebagai Obat Kumur Terhadap Peningkatan ph dan Volume Saliva :Dentino Jurnal Kedokteran Gigi UNLAM, Banjarmasin.

Pratiwi, D, 2007, Gigi Sehat Merawat Gigi Sehari-hari, PT Kompas Media Nusantara, Jakarta.

Riset Kesehatan Dasar, 2013, Kesehatan Gigi dan Mulut, Kementrian Kesehatan Republik Indonesia, Jakarta.

Rukmana, R, 1999, Stroberi Budi Daya dan Pascapanen : Kanisius (Anggota IKAPI), Yogyakarta.

Siswosubroto, A.E, Pengemanan, D.H.C, Leman, M.A, 2015, Gambaran Konsumsi Yoghurt Terhadap Waktu Peningkatan pH Saliva :Jurnal Ilmiah Farmasi, Vol.4, No.4, h.47.48.

Suhartatik, N, Mustofa, A, Harifah, I, 2013, Aktivitas Antioksidan Infused Water Dengan Variasi Jenis Jeruk (Nipis, Lemon, dan Baby) dan Buah Tambahan (Stroberi, Anggur Hitam, dan Kiwi) :Jurnal Ilmiah Tehnologi dan Industri Pangan UNISRI, Vol.1, Hal.1.

Sulihandari dan Hartanti, 2013, Herbal Sayur \& Buah Ajaib: Trans Idea Publishing, Yogyakarta.

Wardhana, 2014, Cara Segar Meminum Air Putih dengan Buah-buahan, http://m.kompasiana.com 